\title{
A Mechanistic Model for Prediction of Cutting Parameters in Micro-Scale Milling
}

Jinfeng Zhang, Chao Feng, Yunhui Ma, Wei Tang, Shuai Wang, Xin Zhong

The College of Mechanical and Electronic Engineering, Shandong University of Science and Technology, Qingdao, 266 590, China. E-mail: zhangjf@sdust.edu.cn,fengchao2018@126.com,791120273@qq.com,674379323@qq.com,243031 0604@qq.com,haifeng2464@163.com

While down-scaling of micro milling process is similar to the conventional process, there are specific issues that differ from macro machining due to higher ratios of feed per tooth to tool radius and tool run-out to tool diameter, size-effect, minimum chip thickness, elastic-plastic deformation, microstructure effects, etc. One of the challenges in micro machining is attaining accurate and reliable machining parameters, which can reduce tool wear and breakage to achieve higher productivity and quality at a lower cost. Therefore, this paper presents a new mechanistic model for predicting the precise process parameters considering material properties and principles of micromilling under various cutting conditions. The proposed model also takes into account the nonlinearity and dynamics of minimum chip-thickness, micro-milling cutting forces considering cutting, as well as edge and damping coefficients into. The predicted stability lobes and the stability limits from experiments are in sufficient agreement. The research of micro-scale milling parameters is significant to improve the precision of machined parts, reduce the wear and tear of the micro-milling blade and extend the life of micro-tools.

Keywords: Micro chatter, Lobe diagram, Spindle speed, Axial cutting depth, Damping effect.

\section{Acknowledgement}

This research is supported by the Foundation for Outstanding Young Scientist in Shandong Province (Grant No. BS2014ZZ007), China Postdoctoral Science Foundation Funded Project (Grant No. 2016M5922165),Qingdao Postdoctoral Applied Research Project(Grant No.2015182) and The Scientific Research Foundation of the SDUST (Grant No. 2014RCJJ023).

\section{References}

[1] SCHMITZ, T. L., SMITH, K.S. (2009). Machining dynamic-frequency response to improved productivity, pp. 45- 78. Springer, New York.

[2] SRINIVASA, Y.V., SHUNMUGAM, M. S. (2013). Mechanistic model for prediction of cutting forces in micro end-milling and experimental comparison. International Journal of Machine Tools and Manufature, vol.67, No.8, pp .18-27.

[3] CHENG, K. (2006). Machining dynamics-fundamentals applications and practices, pp.156-198. Springer, New York.

[4] KOLAR,P., SUliTKA, M.,FOJTU, P.,FALTA, J., ŠINDLER, J.(2016). Cutting Force Modelling with a Combined Influence of Tool Wear and Tool Geometry, Manufacturing Technology, Vol.16, No.3 pp.524-531.

[5] SHI, Y., MAHR,F., WAGNER,U.V., UHLMANN,E.(2012). Chatter frequencies of micromilling processes:influences factors and online detection via piezoactuators. International Journal of Machine Tools and Manufacture, Vol. 56, No,6. pp.10-16.

[6] BACH, P., POLACEK, M., CHVOJAK, P., J. (2014). Dynanics forces in unstable cutting during turning operation. Manufcturing Technology, Vol.14, No.1, pp.3-8.

[7] KING, R.I. (1985). Handbook of high-speed machining technology.pp. 1215-1226. Chapman And Hall. NewYork.

[8] KOLAR, P., SUliTKA, M., FOJTU, P., FALTA, J., ŠINDLER, J. (2016). Cutting Force Modelling with a Combined Influence of Tool Wear and Tool Geometry, Manufacturing Technology, Vol.16, No.3, pp.524-531.

[9] NAKAMOTO, K., KATAHIRA, K., OHMORI, H., YAMAZAKI, K., AOYAMA, T. (2012). A study on the quality of micro-machined surfaces on tungsten carbide generated by PCD micro end-milling. Manufacturing Technology, Vol.61, No.1, pp. 567-570.

[10] BASCHIN, A., KAHNIS, P., BIERMANN, D. (2014). Dynamic analysis of the micromilling process influence of tool vibration on the quality of microstructures. Mat.-wiss.u.Werkstofftech, Vol.39, No.9, pp.616-621.

[11] QUINTANA, G., CIURANA, J. (2011). Chatter in machining Processes: A review. International Journal of Machine Tools and Manufacture, Vol.51, No.15, pp.363-376. 
[12] Xu, S.G., Ba, J.J., CHEN, X.F., ZHENG,T., YANG,Y.C., Guo,L. (2016). Predicting strata temperature distribution from drilling fluid temperature, International Journal of Heat and Technology, Vol. 34, No. 2, pp. 345-350.

[13] FENG, F.P., AI, C., XU, H.S., CUI, Z.H., GAO, C.L. (2015). Research on the condition model of drilling fluid non-retention in eccentric annulus, International Journal of Heat and Technology, Vol. 33, No.1, pp. 9-16.

[14] JUN,M.B. G., LIU,X.Y., DEVOR,R. E., KAPOOR,S. G. (2006). Investigation of the dynamics of microend milling-Part1: Model development. Journal of Manufacturing Science and Engineering, Vol. 128, No.11, pp. 893 900 .

[15] JUN,M.B. G., LIU,X.Y., DEVOR,R. E., KAPOOR,S. G. (2006). Investigation of the dynamics of microend milling-Part 2:Model validation and interpretation. Journal of Manufacturing Science and Engineering, Vol.128, No.11, pp.901-912.

[16] LI, H. Z., LI, X. P., CHEN, X.Q. (2003). A novel chatter stability criterion for the modeling and simulation of the dynamic milling process in the time domain. International Journal of Advanced Manufacturing Technology, Vol.22, No.7, pp.619-625.

[17] SONG, Q.H., LIU, Z., SHI, Z. (2014). Chatter stability for micro-milling processes with flat end mill. International Journal of Advanced Manufacturing Technology, Vol.71, No.9, pp.1159-1174.

Copyright (C) 2017. Published by Manufacturing Technology. All rights reserved. 